\title{
Do Human Resources Have More Value Than The Cost Incurred On Them By The Organisation ? An Empirical Analysis Of INFOSYS Ltd. Using Contribution-Based Model
}

\author{
Mukesh Kumar Meena ${ }^{1,}{ }^{*}$, Vijay Kumar Shrotryia ${ }^{1}{ }^{\dagger}$ and Ajay Kumar \\ Singh ${ }^{1,2, ~} \ddagger$
}

${ }^{1}$ Faculty of Commerce and Business, Delhi School of Economics, University of Delhi, India. and ${ }^{2}$ Sri Sri University, Cuttack, Odisha, India

*mkkalot@gmail.com

†vkshro@gmail.com

‡drajayksingh@gmail.com

\begin{abstract}
Employees always play an important role in the service sector. For this study, we have selected Infosys Ltd. as a leading company in the IT sector. The study's objective is to analyze the expenditure incurred by Infosys Ltd. on their employees and the value of employees' contribution to Infosys Ltd. using the Human Resources Information System (HRIS), a contribution-based model that consists of 13 variables. Out of the 13 variables, 09 variables are monetary. We have collected data from the latest financial reports of Infosys Ltd. and the Reserve Bank of India's database for eight monetary variables. Four out of 13 variables are non-monetary for which data have been collected with the help of a standardized questionnaire using 5 points Likert scale. Based on the responses received from 119 employees of Infosys Ltd. and by analyzing data we conclude at both the individual and organization levels that there is a difference between the expenditure incurred by Infosys Ltd. on their employees in total and the Value of all employees' contribution as an individual and as a group towards Infosys Ltd. This means that the employees' contributions both individually and collectively are much more than the cost incurred by the organization.
\end{abstract}

Keywords: Human Resource Accounting; Employee Contribution; Service sector; Cost of employees; Value of employees.

\section{Introduction}

In the beginning, competitive advantage is gathered by the organization by developing a new product and production system. Later on, organizations moved towards the organizational structure and process to achieve a competitive edge. The development of technologies in the area of communications, informatics, and biology in the recent period has augmented a knowledge society where service sector has the largest contribution to the gross domestic product of an economy. In a service-oriented economy, employee's skills, competence, thoughts, energy, and decision-making capacity are recognized as driving forces in achieving the ultimate success of an organization. 
In the highly competitive and globalized environment where each firm has access to the latest technology and having sufficient availability of funds, the success of the organization depends upon the skills, competence, and managing capacity of the employees. Now, employees in the organizations are recognized as human capital, also known as human assets. Likert (1967) explains the violation of accounting's accrual principle of disclosure in the absence of human resources as an asset in the balance sheet. The absence of human resources in the balance sheet underrated the organization's net worth and current income. As per Likert's observation, the financial reports do not reflect the true and fair view of the organization in the absence of human resources from the balance sheet. The definition of human resources accounting is explained by the American Accounting Association, in its report published in 1966, as, "the process of identifying, measuring, and communicating economic information to permit informed judgments and decisions by users of the information".

If we look at the past developments in the area of human resource accounting, there are multiple approaches for the measurement of human resources. But still, the majority of organizations are not following human resource accounting practices. Is there any difference between the expenditure incurred by the organization on the employees and their value to the organization? Can the value of all values be calculated just by adding the individual employee's value? What are the possible reasons for the gap? Some monetary-based models focus on the cost and value concept. Then some non-monetary models consider non-monetary variables like job satisfaction, skills, employee potential, etc. Does the expenditure incurred by an organization on its employees be the sole criteria for the measurement of human resources? As the monetary-based models suffer from the limitations of conventional accounting, Are non-monetary variables related to a particular organization sole criteria for the measurement of human resources?

\section{Review of Literature}

Table 1. Historical development of Human Resource Accounting

\begin{tabular}{ll}
\hline In Stage I & Origin of the development of the concept (Primary) and theories of Human Resources Accounting. \\
\hline $1960-1966$ & \\
\hline In Stage II & $\begin{array}{l}\text { During this phase, some of the basic measurement models of human Resource Accounting } \\
\text { developed. }\end{array}$ \\
\hline $1967-1970$ & \\
\hline In Stage III & The period of rapid development of interest levels in Human Resources Accounting. \\
\hline $1971-1977$ & \\
\hline In Stage IV & $\begin{array}{l}\text { The period of stagnant interest level by academicians. More substance on fixed assets of the organizations led to the diminution of interest in HRA at } \\
\text { organizations and universities level. }\end{array}$ \\
\hline I978-1980 & $\begin{array}{l}\text { This stage marked the resurgence of global interests in theories and development } \\
\text { In Stage V }\end{array}$ \\
\hline $1981-1990$ & \begin{tabular}{l} 
Thuman resources Accounting. \\
\hline In Stage VI
\end{tabular} \\
\hline $1990-$ now & constructive in the process of managerial decision making. \\
\hline
\end{tabular}

Source: (Flamholtz et al., 2002) and further development by other authors

After analyzing the development of the human resource accounting concept (Table 1), the models of Human resources accounting can be divided into three groups, viz., (1) Monetary models, (2) Non-monetary models, and (3) Composite Models. Monetary models can be further categorized as cost concept-based models, and value conceptbased models. The cost-based models consider human resources as a cost to the organization and the expenditure incurred on the employees is treated as a cost to the organization. Some of the major cost-based concept models are as follows: Historical costs (Brummet et al., 1968), Replacement Cost Model (Likert, 1973) and (Flamholtz, 1973), opportunity cost model (Hekimian \& jones, 1967), Standard cost model, and Current purchasing power model (CPPM). The value-based model has utilized the concept of the future value of a present investment using the capitalization concept. Some of the major value-based concept models are as follows: Unpurchased goodwill model (Hermanson,1964), Net adjusted present value model (Hermanson, 1964), The present value of future earning model (Lev \& Schwartz, 1971), Reward valuation model (Flamholtz, 1971), Human asset multiplier method (Robinson, 1972), Net benefit model (Morse, 1973), Jaggi and Lau model (Jaggi and Lau, 1974), HR valuation model (Friedman and Lev, 1974), Certainty equivalent net benefits model (Ogan, 1976) and Aggregate payment model (Chakraborty, 1976).

Further, some of the models were developed which were considering only non-monetary variables. Some of the models are as follows: causal, intervening, and end-result variable Model (Likert and Bowers, 1969), Behavioural model (Myers \& Flowers, 1974), and Behavioural (Social and Psychological) Model (Flamholtz, 1972b). Based on the Americans' contributions both individually and (of the Committee on Human Resource Accounting, 1973) suggestions, some of the contribution-based models were developed, which consists of both monetary variables as well as 
non-monetary variables. One of the useful contribution-based models is the human resource information system (HRIS) (Singh, 2002a). Monetary models are developed by utilizing the monetary variables while non-monetary models are constructed by using the behavioral variables. The composite models recognized both monetary as well as behavioral variables for the development of measurement models.

Historical cost models are based on the conventional accounting concept of matching (Brummet et al., 1968). Opportunity cost model does not account for employees, who are not being bid by the other department of the organization (Hekimian and jones, 1967). The adjusted present value model has a drawback that it operates with an estimation of the probability that an individual will occupy each state in the set of mutually exclusive states model (Hermanson, 1964). The human capital model Friedman and Lev (1974) does not take into account the effect of mobility of employees before death on earnings. The behavioral model Likert and Bowers (1969) considers the linear association between casual, intervening, and end-result variables which reduces the level of reliability. The main drawback of Lev and Schwartz's model (Lev and Schwartz, 1971) is that it is based on the concept of ignorance of the variables of employees' career movements within the organization and the chances of employees' departure from the organization before their retirement or death. The core assumption of Flamholtz's model is that individual employees shift through a set of mutually exclusive organizational roles, in general, the prediction with certainty is not possible which "state" an individual will occupy at a future point in time, the model operates with an estimation of the probability that an individual will occupy each state in the set of mutually exclusive states (Flamholtz, 1971).

Considering the limitations of the earlier models, the HRIS model (Singh, 2002a) seems to be considered for being comprehensive considering the qualitative and quantitative aspects. It considers both monetary and nonmonetary variables, the employees' monetary value depends upon several non-monetary (qualitative) variables. The model associates the employee's competence and activation levels with the incentive system that influences the productivity as well as the job satisfaction level of an employee. The variables related to promotability and organizational memberships are also determined by using the statistical probability method to estimate the employee's realizable value to the organization.

Several approaches have been suggested to measure the cost and benefit of employees to organizations. The concepts underlying these approaches are basically the same as those used for non human (physical) asset valuation (e.g. historical cost, replacement cost, etc.). Consequently, these approaches share the well-known conceptual and practical problems involved in accounting measurements, such as the irrelevance of historical cost and the problems of estimating future service potential. The approach for the measurement of the firm's investment in human resources rests on the generally accepted concept of asset valuation but departs from conventional accounting practices by incorporating both actual and market values in the measurement process. But the further development is human resource accounting models still have limitations of conventional accounting. (of the Committee on Human Resource Accounting, 1973) suggested considering the non-monetary variables and monetary variables together to know the exact contribution of human resources towards an organization. The expenses on human resources by the organization cannot be considered as a substitute measure of estimating the human resources contribution in the organization. Because it is based on conventional accounting. Essentially, the human resources investment is measured by discounting the stream of cost savings resulting from the firm's specific personnel policies (e.g., training, health care, etc.). However, it should be noted that the investment measure is only a surrogate since it does not fully reflect the benefits of the human resource investment (Friedman and Lev, 1974). In this study, we are analyzing the contribution of human resources towards the organizations by considering monetary as well as non-monetary variables. Based on the above literature we propose the following hypothesis:

Hypothesis 2.1. There is a difference between the expenditure incurred by Infosys Ltd. on their employees individually and the Value of individual employees' contribution towards Infosys Ltd.

A group of employees may contribute more towards the organization in comparison to an individual employees. The group does not mean essentially working in the same department of the organization; they may be working in different departments at the same rank in the organization. The value of human resources can be calculated conveniently based on group concepts. The employees' value produced on such a premise will be more dependable and can be utilized for choices identifying with HR. With the use of this idea, we will actually want to anticipate with more prominent accuracy the professional developments of the human resources inside the firm and the odds of their leaving the firm whenever. It is difficult to predict how long a particular individual intends to stay in the firm, or how long he is likely to work at a particular position; but, on a group basis, it turns out to be not difficult to determine the level of representatives of a specific gathering prone to leave the firm during every one of the approaching time frames or to be elevated to higher positions. This idea expects that the example of development is probably going to stay consistent except if uncommon conditions warrant a change. In the case of a change in the circumstances, a change in the pattern of movement can be predicted and incorporated into the model well ahead of time (Jaggi and Lau, 1974).

Based on the above literature we propose the following hypothesis:

Hypothesis 2.2. There is a difference between the expenditure incurred by Infosys Ltd. on their employees in total and the Value of all employees' contribution as a group towards Infosys Ltd. 
As we know employees are the important assets for the survival of the organization and they should be valued like other intangible assets and should be disclosed in the balance sheets. Human assets significantly affected the investment decision and human resources-related policies of the management (Singh and Gupta, 2014).

Various studies have been conducted on various aspects pertaining to usefulness of information, provided by Human resource accounting, on the decision making by investors (Isaac et al., 2017; Sharma and Sharma, 2013; Chouhan and Naghshbandi, 2015; Abiola and Adisa, 2020; Hanini, 2018; Avazzadehfath and Raiashekar, 2011; Enyi and Akindehinde, 2014; Elias, 1972; Hendricks, 1976; Singh and Gupta, 2014; Likert and Bowers, 1973; Singh and Gupta, 2014; Brummet et al., 1968; Flamholtz and Main, 1999; Al-Tahat and Al-Zoubi, 2020; Singh and Vasudeva, 2014; Likert and Pyle, 1971; Flamholtz, 1972a; Gambling, 1974; Jaggi and Lau, 1975; Morse, 1975; Likert, 1977; Dittman et al., 1980; Arkan, 2016; Baligh and H.; Bechtel, 2007; Ployhart and Moliterno, 2011; Singh and Gupta, 2008, 2010; Do et al., 2019; More and Reimer, 1956; Pecorella et al., 1978; Ryder, 1975; Sinha et al., 2010; Singh and Sharma, 2011a,b; Katz et al., 1951; Morse, 1953; Likert, 1932, 1973, 1979; Sinclair, 1991; Singh, 2002b; Singh and Jain, 2013).

\section{Research Methodology}

The major contributor to the GDP is the service sector in India as well as in most of the developed countries, out of which the IT sector has the major contribution. Infosys Ltd. is one of the leading companies in India, from the IT sector which used to report information about human resources accounting as part of the annual report, therefore, Infosys Ltd. was selected for the study.

The objective of the study is to analyze the value of an employee's contribution to Infosys Ltd. using the Human Resources Information System (HRIS) (Singh, 2002a) which is a

The contribution-based model consists of 13 variables, out of which, 09 variables are monetary for which data is given in Table 2. The latest financial reports of Infosys Ltd. and the Reserve Bank of India's database have been used for data collection. For four non-monetary variables data have been collected with the help of a standardized questionnaire using 5 points Likert scale. We have shared the questionnaire with the employees of Infosys Ltd through face-to-face mode at the Gurugram office and there were 1100 employees in the IT division. We have reached 300 employees of Infosys Ltd. at the Gurugram office. Through online mode, we have shared questionnaires randomly via LinkedIn and email to 450 employees at all India levels. We have received total responses from 119 employees of Infosys Ltd. These 119 employee responses were selected for human resource valuation as per the contribution-based model HRIS (Singh, 2002a).

Table 2. Variables of the Human Resources Information System (HRIS) (Singh, 2002a)

\begin{tabular}{|c|c|}
\hline Variables & Source of the data/Scale \\
\hline Acquisition Cost & From the Financial Reports of the Organisation \\
\hline Development Cost & From the Financial Reports of the Organization \\
\hline Current Retention Cost & From the Financial Reports of the Organization \\
\hline Current Performance Appraisal Index & $\begin{array}{l}\text { Through a standardized questionnaire } \\
\text { (Pradhan, \& Jena, 2017) }\end{array}$ \\
\hline Job Satisfaction Index & $\begin{array}{l}\text { Through a standardized questionnaire } \\
\text { (Brayfield \& Rothe, 195; Judge et al., 1998) }\end{array}$ \\
\hline Future Retention Cost & From the Financial Reports of the Organization \\
\hline Potential Appraisal Index & $\begin{array}{l}\text { Through a standardized questionnaire (Gupta \& Sahoo, 2016; } \\
\text { Tafarodi \& Swann, 1995; Eby \& Dobbins, 1997; Ashford, 1988; } \\
\text { Jimmieson et al., 2004; Wiemann, 1977) }\end{array}$ \\
\hline Experience Index & Through standardized questionnaire's demographic information \\
\hline Organizational Climate Index & Through a standardized questionnaire (Peña-Suárez et al., 2013) \\
\hline Efficiency Index & $\begin{array}{l}\text { From the Financial Reports of the Organization and RBI Reports } \\
\text { (Dbie-Rbi, 2020) }\end{array}$ \\
\hline Labour Turnover Index & $\begin{array}{l}\text { From the Financial Reports of the Organization and RBI Reports } \\
\text { (Dbie-Rbi, 2020) }\end{array}$ \\
\hline Labour Unrest Index & From the Financial Reports of the Organization and Reports \\
\hline Output Per Employee & $\begin{array}{l}\text { From the Financial Reports of the Organization and RBI Reports } \\
\text { (Dbie-Rbi, 2020) }\end{array}$ \\
\hline
\end{tabular}

To check the consistency of the questionnaire used in our study for primary data collection for four variables, we have used the Cronbach's Alpha reliability test in the SPSS Software. Table 3 is giving brief analysis results of a reliability test of the questionnaire conducted in SPSS Software.

To explain the variable job satisfaction index of the Human Resources Information System (HRIS) (Singh, 2002a), five states have been used in the scale on a five-point Likert scale. For the job satisfaction index, we have used the standardized scale developed by (Brayfield and Rothe, 1951) (Judge et al., 1998) studies. And the SPSS outcomes for Cronbach's Alpha are 0.708 for the job satisfaction index. And Cronbach's Alpha above 0.7 is considered to be 
good. That shows the internal consistency of the job satisfaction index scale is good concerning our primary data collection through responses from Infosys Ltd employees.

To explain the current performance appraisal index of the Human Resources Information System (HRIS) (Singh, 2002a), 23 statements have been used on the five-point Likert scale. For the Potential Appraisal Index, we have used the standardized scale developed by (K. and K, 2016), (Tafarodi and Swann, 1995), (Eby and Dobbins, 1997), (Ashford, 1988), (Jimmieson et al., 2004) and (Wiemann, 1977). And the SPSS outcome for the Cronbach's Alpha is 0.939 for the Potential Appraisal Index. And Cronbach's Alpha above 0.7 is considered to be good. That shows the internal consistency of the Potential Appraisal Index scale is good concerning our primary data collection through responses from Infosys Ltd employees.

To explain the Organizational Climate Index of the Human Resources Information System (HRIS) (Singh, 2002a), 15 statements have been used on the five-point Likert scale. For the Organizational Climate Index, we have used the standardized scale developed by (Suarez et al., 2013) and the SPSS outcome for the Cronbach's Alpha is 0.873 for the Organizational Climate Index. And Cronbach's Alpha above 0.7 is considered to be good. That shows the internal consistency of the Organizational Climate Index scale is good concerning our primary data collection through responses from Infosys Ltd. employees.

Table 3. Reliability Test for Non-Monetary variables

\begin{tabular}{lcc}
\hline Factors & No. of Items & Cronbach's Alpha for Employees \\
\hline Job Satisfaction Index & 05 & 0.708 \\
Current Performance Appraisal Index & 23 & 0.907 \\
Potential Appraisal Index & 27 & 0.939 \\
Organizational Climate Index & 15 & 0.873 \\
\hline
\end{tabular}

\subsection{Data Analysis}

Table 4. Responses from employees of Infosys Ltd. = 119

\begin{tabular}{|c|c|c|}
\hline Particulars & Number & $\%$ (out of 119 ) \\
\hline \multicolumn{3}{|c|}{ Age Group (in Years) } \\
\hline$<30$ & 85 & 71.42 \\
\hline 30 and Above & 34 & 28.57 \\
\hline \multicolumn{3}{|c|}{ Gender } \\
\hline Female & 63 & 52.94 \\
\hline Male & 56 & 47.05 \\
\hline \multicolumn{3}{|c|}{ Qualification } \\
\hline $\begin{array}{c}\text { Professional- MBA/CA/LLB/ } \\
\text { Engineering }\end{array}$ & 80 & 67.22 \\
\hline $\begin{array}{l}\text { Non-Professional - Post } \\
\text { Graduation/Under Graduation }\end{array}$ & 39 & 32.77 \\
\hline \multicolumn{3}{|c|}{ Experience } \\
\hline$<05$ Years & 45 & 37.81 \\
\hline 05 Years \& Above & 74 & 62.18 \\
\hline \multicolumn{3}{|c|}{ Rank/Cadre of Employees } \\
\hline Manager/Engineer & 49 & 41.17 \\
\hline Consultant & 41 & 34.45 \\
\hline Technology Analyst & 29 & 24.36 \\
\hline
\end{tabular}

\subsection{Measurement of Individual Human Resource Value}

As in the above table, there is a clear difference between the cost incurred on employees and employee value calculated as per Human Resources Information System (HRIS) (Singh, 2002a). The HRIS (Singh, 2002a) considers non-monetary variables like the Index of performance appraisal, Experience Index, Index of Potential appraisal, Index of job Satisfaction while calculating the human resources accounting value of an organization's employee. These non-monetary factors create the difference between the monetary expenditure on employees by the organi- 
Table 4A - Individual Employee's Average Valuation as per Human Resources Information System (HRIS) (Singh, 2002a)

\begin{tabular}{|c|c|c|c|c|c|c|}
\hline $\begin{array}{l}\text { No. of Employees } \\
\text { taken for study } \\
\text { from INFOSYS }\end{array}$ & $\begin{array}{c}\text { AVERAGE Total Cost } \\
\text { (Avg Current Cost }+ \\
\text { Avg Future Cost) }\end{array}$ & $\begin{array}{c}\text { AVERAGE. } \\
\text { CURRENT } \\
\text { PERFORMANCE } \\
\text { APPRAISAL } \\
\text { INDEX }\end{array}$ & $\begin{array}{l}\text { AVERAGE JOB } \\
\text { SATISFACTION } \\
\text { INDEX }\end{array}$ & $\begin{array}{l}\text { AVERAGE } \\
\text { POTENTIAL } \\
\text { APPRAISAL } \\
\text { INDEX }\end{array}$ & $\begin{array}{l}\text { AVERAGE } \\
\text { EXPERIENCE } \\
\text { INDEX }\end{array}$ & $\begin{array}{l}\text { AVG HUMAN } \\
\text { RESOURCES VALUE } \\
\text { (INDIVIDUAL } \\
\text { EMPLOYEE) }\end{array}$ \\
\hline 119 & 2099550 & 1.485568 & 1.134454 & 1.459072 & 5.718487 & 20647315 \\
\hline
\end{tabular}

zation and the employees' value of that organization. In the Human Resource Information System (HRIS) (Singh, 2002a) model, the value of human resources is calculated on the basis of the contribution made by the employee in the organization. That contribution consists of both monetary factors as well as non-monetary factors. The performances of an organization, productivity, growth, etc. are affected by the experience, satisfaction level, potential, efficiency, education, values, morals, behavior, education, etc. of the employees working for that particular organization.

There is a statistically significant difference between the expenditure incurred by Infosys Ltd. on their employees individually and the Value of individual employees' contribution to Infosys Ltd.

From the above data results of human resources cost and human resources value for Infosys ltd, and thus accepts the alternative hypothesis "Hypothesis 2.1 " that there is a difference between the value of Infosys Limited's employees and the cost incurred by Infosys Ltd. on their employees.

For Infosys Ltd., we have considered 119 employees. In Table no. 4A, we have provided information about human resources cost and human resources value. We have observed that for all the 119 employees the value of human resources is much higher than the human resource cost incurred by Infosys Ltd. on each employee. That indicates the employee's contribution towards the organization is much more than the expenditure incurred by the organization on its employees. That means the expenditure incurred on employees is not a sole indicator of the value of human resources. Employees are contributing much more than the expenditure incurred by the organization on its employees.

That means the employees have contributed more resources towards organizations in comparison to the organization's contribution towards employees. That shows the value of Infosys Ltd employees is much more than the cost of its employees. That is only possible when all the employees are contributing to their organization. And that contribution is much higher than the cost of employees because of the efficiency, satisfaction level, motivation, potential, education, experience, etc. of the employees working for that particular organization.

From Table 4A results, we can see that employee number "INFOSYS 93" has a higher value (i.e., 1.93) for the current performance appraisal index, (i.e., 1.5) value for job satisfaction index, (i.e., 1.9) for potential appraisal index and only 6 for experience index. But overall, this employee has secured 15th rank out of 119 employees for human resources value. This employee has a medium value for experience index, but due to the high values of current performance appraisal, potential appraisal, and job satisfaction index, this employee secured a good rank in comparison to other employees. That means the management should focus on retaining this employee for the long term.

In case no. "INFOSYS22", the employees have a high value (i.e., 10.5) for experience index. But still, the employee can secure 30th rank out of 119 employees for human resource value. The reason for this comparatively lower rank is the value of the job satisfaction index. This employee has a moderate (i.e., 1) value in the job satisfaction index. So, Infosys Ltd. should focus on such high experience valued employees for their job satisfaction level. If the employee has better job satisfaction, he must have secured a better rank. Because of the high value of the experience index, this employee has a good amount of working knowledge and skills that's why he can perform better. This employee has above the moderate value (i.e., 1.3) for the current performance appraisal index. As soon as the job satisfaction value will increase for this employee, this employee will be able to perform better for the organization.

If we look at case no. "INFOSYS15", this employee has secured 82nd rank out of 119 employees. This employee is having a very low value in the experience index. That is the reason for his lower rank in the human resource value index. But these employees have a higher value in the job satisfaction index (i.e., 1.6). That indicates the employee is highly satisfied with his job. Also, the potential appraisal index is showing a higher value (i.e., 1.9) for this employee. That means the employee has a good number of skills and knowledge. Again, if we look at the current appraisal index for this employee, that is also an indication of high value (i.e., 1.4) for the current performance appraisal index. That indicates this employee can perform well in all duties and responsibilities at the workplace. The organization should have some policies to retain highly satisfied and skilled employees. As the experience of such kinds of employees will increase with the organization, their contribution towards the organization will increase multiple times.

\subsection{Measurement of Total Human Resources Value (THRV)}

As per the Human Resources Information System (HRIS) (Singh, 2002a), we have calculated the value of individual employees for Infosys Limited for further valuation as per the Human Resources Information System (HRIS) (Singh, 
2002a) model, total human resources value will be calculated for Infosys Ltd. For calculating the total human resource value, we will consider the individual human resource value with the index of organizational climate index, Efficiency index, labor turnover index, labor unrest index, and output per employee index.

For the valuation of the total human resource value, the Human Resources Information System (HRIS) (Singh, 2002a) shall be used. This is as follows:

$$
\text { Total Human Resource Value }(\mathrm{THRV})=(X 1+X 2+X 3+\ldots \ldots+X n)(\mathrm{OCI})(E F I)(L T I)(L U I)(O P E)
$$

Where:

$\mathrm{X} 1, \mathrm{X} 2, \mathrm{X} 3 \ldots . \mathrm{Xn}$ is the value of individual human resources of that particular organization calculated as per the Human Resources Information System (HRIS) (Singh, 2002a) model.

OCI = Organizational Climate Index EFI = Efficiency Index

LTI = Labour Turnover Index

LUI = Labour Unrest Index

OPE = Output per Employee Index

\subsection{Statistics for Various Industry Level Macro Factors:}

$$
\begin{aligned}
& \text { Industry's Efficiency }=\frac{\text { Total Output of the Industry }}{\text { Total Input of the Industry }} \\
& \qquad \frac{80721730000000}{66052020000000}=1.22 \\
& \text { Industry's Output per Employee }=\frac{\text { Total Number of Employees Engaged in the Industry }}{\text { Industry's Output }} \\
& =\frac{80721730000000}{15614619}=5169625.33 \\
& \text { Industry's Labour Unrest }=\frac{\text { Man }- \text { days Lost due to Strikes and Lockouts }}{\text { Total man - days Work }} \\
& \frac{1273770}{30104985432}=4.23 \%
\end{aligned}
$$

Table 5. Industry-level factors

\begin{tabular}{lc}
\hline Parameters & Service Industry \\
\hline The efficiency of the Industry (based on input-output ratio) & 1.22 \\
Labour Turnover of the Industry (\%) & 16.57 \\
Labour Unrest of the Industry (\%) & 4.23 \\
Output Per Employee in the Industry (Rs.) & 5169625.33 \\
\hline
\end{tabular}

Source: Reserve Bank of India.

Table 5 is expanding the Human Resources Information System (HRIS) (Singh, 2002a) model's variable value. The above data for variables have been collected from the latest reports released on the Indian economy by DBIE-RBI 
(Dbie-RBI, 2020).

This is a database of the Indian economy. This data warehouse is managed by the Department of Statistics and Information Management (DSIM), under the Reserve Bank of India.

We have collected the information from the DBIR-RBI (Dbie-RBI, 2020)database as per the requirements for human resources accounting based on the Human Resources Information System (HRIS) (Singh, 2002a) model. The efficiency ratio of the service Industry is 1.22 as per the DBIR-RBI (Dbie-RBI, 2020) database. This is based on the input-output ratio of the industry. That is indicating the output results based on the input used by the industry. As per the DBIR-RBI (Dbie-RBI, 2020) database, we can easily explain that the industry can produce 1.22 units of output by taking the 1 unit of input.

Further, we also analyzed the labor turnover rate from the DBIR-RBI (Dbie-RBI, 2020) database. The labor turnover rate is 16.57 percent. This is the percentage of employees leaving and joining the industry with existing employees in a particular period.

Further, we also analyzed the (Dbie-RBI, 2020) database for Labour Unrest in the Industry. And the database is showing 4.23 percent labor unrest in the industry caused by employees' protests, strikes, lockouts, etc. which is a ratio of man-days lost due to employees' protests, strikes, lockouts, etc. to the total man-days of the industry in a particular period.

By further analyses of DBIR-RBI (Dbie-RBI, 2020) databases we also found the value for Output per Employee in the Industry. The DBIR-RBI (Dbie-RBI, 2020) database indicates Rs. 5169625.33 as the Output per Employee in the Industry. This is the ratio of the total output of the industry to the total number of employees in the industry in a particular period.

\subsection{Statistics on Organizational Level Factors for THRV (Singh, 2002a)}

Table 6. Organizational Level Factors for THRV

\begin{tabular}{ll}
\hline Parameters & Infosys Ltd. \\
\hline $\begin{array}{l}\text { Total Value of Individual } \\
\text { Human Resources (Rs.) }\end{array}$ & 2457030465 \\
$\begin{array}{l}\text { Organisation Climate Index } \\
\text { Labour Turnover Rate }\end{array}$ & 1.45 \\
$\begin{array}{l}\text { (Attrition rate) (\%) } \\
\text { Labour Unrest }\end{array}$ & 21.7 \\
$\begin{array}{l}\text { Organization's efficiency } \\
\text { (Asset Turnover Ratio) }\end{array}$ & 1.02 \\
Output per employee (Rs.) & $38,27,520$ \\
\hline
\end{tabular}

Table 6 is showing the values of the Human Resources Information System (HRIS) (Singh, 2002a) model's variables at the organization level. With the help of the Human Resources Information System (HRIS) (Singh, 2002a) model we have calculated the value for individual human resources of a particular organization and we have received responses from 119 employees of Infosys Ltd.

The sum of individual human resource valuation is Rs. 2457030465 . This value has been calculated using the Human Resources Information System (HRIS) (Singh, 2002a) model for each employee. Then we have summated the individual human resource value of 119 employees.

$$
X_{1}=[(A C+D C+C R C) * K P A I * J S I]+[F R C * P A I] * E I
$$

Where: $X_{1}=$ Value of one employee having number 1

$\mathrm{AC}=$ Acquisition Cost

DC $=$ Development Cost

$\mathrm{CRC}=$ Current Retention Cost (Gross Emoluments including maintenance and separation cost)

KPAI = Current Performance Appraisal Index (Key Performance Area Index)

JSI = Job Satisfaction Index

FRC $=$ Future Retention Cost

PAI = Potential Appraisal Index

$\mathrm{EI}=$ Experience Index

Table 6 showing that the value for the organization climate index is 1.45 . This is a moderate to high value. That shows the working environment at Infosys Ltd. is attractive for employees. This value has been calculated with the help of a standardized questionnaire based on a 5-point Likert scale. For the Organizational Climate Index, we have used the standardized scale developed by (Suarez et al., 2013). 
Table 6 shows the labor turnover rate for Infosys Ltd. is 21.7 percent. This information has been collected from the financial reports of Infosys Ltd. if we look at the DBIE-RBI (Dbie-RBI, 2020) data for Labour Turnover of the Industry, which is $16.57 \%$. That means Infosys Ltd. has a higher labor turnover rate than the industry.

We have not observed any information about labor unrest in the financial reports of Infosys Ltd. which means there was no disturbance caused in the organization's work due to strikes, lockouts, etc. and that's why we have considered 1 value for the labor unrest index. That indicates no labor unrest in Infosys Ltd.

By further analysis of the financial report of Infosys Ltd., we also found the information for the Organization's efficiency (Asset Turnover Ratio). For the calculation of the Organization's efficiency, we have used the asset turnover ratio. The asset turnover ratio indicates how much value of turnover or output the organization can produce using the 1 unit of its assets. That means it is the ratio of turnover to the asset. For Infosys ltd, it is 1.02 This means Infosys ltd has 1.02 units of output per unit of assets.

Further analyzing the financial reports of Infosys Ltd., we observe the Output per employee (Rs.). This is the ratio of total output to the total number of employees. For Infosys ltd. we observed that Infosys ltd. has Rs. 38, 27,520 outputs per employee.

\subsection{Measurement of Total Human Resource Value (THRV) (Singh, 2002a)}

Table 7. Measurement of Total Human Resource Value (THRV)

(Singh, 2002a)

\begin{tabular}{ll}
\hline Parameters & Infosys Ltd \\
\hline The total value of Individual Employees & 2457030465 \\
Organizational Climate Index & 1.45 \\
Labour Turnover Index & 0.76 \\
Labour Unrest Index & 1 \\
Efficiency Index & 0.83 \\
Output Index (Per Employee) & 0.74 \\
Total Human Resource Value (THRV) & $1,663,037,138.986$ \\
(Singh, 2002a) (Rs.) & \\
\hline
\end{tabular}

As Table 7, the sum of the total value of Individual Employees (119 employees) is Rs. 2457030465 for Infosys Ltd. This value has been calculated as the Human Resource Value (THRV) (Singh, 2002a) for the individual employee.

In Table 7, we have explained the Organizational Climate Index. This is 1.45 for Infosys Ltd. the ratio showing that the value for the organization climate index is 1.45 . This is a moderate to high value. That shows the working environment at Infosys Ltd. is attractive for employees. This value has been calculated with the help of a standardized questionnaire based on a 5-point Likert scale. For the Organizational Climate Index, we have used the standardized scale developed by (Suarez et al., 2013).

Further the Table 7 is explaining the value for the Labour Turnover Index, which is 0.76. This is the ratio of organizational Labour Turnover and industry level Labour Turnover. That indicates Infosys ltd. has a higher labor turnover in comparison to the industry.

Further, Table 7 also explains the Efficiency Index value, which is 0.83 . This is the ratio of the Efficiency Index at the organization level with the Efficiency Index at the industry level.

Further, Table 7 is also explained by the Output Index (Per Employee) value, which is 0.74 . This is the ratio of Output per Employee at the organization level and Output per Employee at the industry level.

There is a statistically significant difference between the expenditure incurred by Infosys Ltd. on their employees in total and the Value of all employee's contributions as a group towards Infosys Ltd.

Further, Table 7 is showing the Total Human Resource Value (THRV) (Singh, 2002a) for Infosys Ltd., which is 1,663,037,138.986. This value has been calculated using the Total Human Resource Value (THRV) (Singh, 2002a). All the above variables explained in table no.7 have been used to calculate Total Human Resource Value (THRV) (Singh, 2002a) for Infosys Ltd. This value indicates the monetary value of 119 employees' total contribution to the organization. This is much higher than the cost incurred by the organization of 119 employees. Here accept the alternative Hypothesis 2.2

That indicates, there is a difference between the expenditure incurred by Infosys Ltd. on their employees in total and the Value of all employees' contribution as a group towards Infosys Ltd.

In this study, we have used the contribution-based model Human Resources Information System (HRIS) (Singh, 2002a) for the valuation of human resources. By analyzing Infosys Ltd. data we conclude at the organization level that there is a difference between the expenditure incurred by Infosys Ltd. on their employees in total and the Value of all employees contribution as a group towards the Infosys Ltd. from the data analysis results we also conclude at individual employee level that there is difference between the expenditure incurred by Infosys Ltd. on their employees individually and Value of individual employees contribution towards the Infosys Ltd. 
From the above results, we can easily conclude that the contribution of Infosys Ltd. employees towards the organization is much more than the expenditure incurred by Infosys Ltd. on their employees.

\subsection{Discussion}

The initial models of human resource accounting were essentially cost-based; however, we cannot consider only the expenditure incurred by the organization on individual employees as a sole criterion for individual human resource contribution. The expenditure on human resources by the organization cannot be considered as a surrogate measure of the contribution of human resources in the organization, just because it is based on conventional accounting, which was considered to be the main drawback of cost-based models. The criticisms of cost-based models led to the emergence of value-based models, largely based on the discounting of future earnings of the employees. Although this discounted cash flow of future earnings of an employee was the value to the employee instead of being the value to the organization.

The human resources investment is estimated by discounting the stream of cost savings resulting from the firm's specific personnel policies (e.g., training, health care, etc.). However, it should be noted that the investment measure is only a surrogate since it does not fully reflect the benefits of the human resource investment. (Friedman and Lev, 1974).

The criticisms of cost-based and value-based models led to the rise of non-monetary models like the model developed by Likert and Bowers (1973).

The changes in the level of technical proficiency, leadership styles, managerial behavior, organizational structure (called the causal variables) result in changes in loyalties, motivation, perception, behavior, attitudes of subordinates (called the intervening variable) which produce changes in manpower development, productivity, cost revenue, innovation, output, quality (called the end-result variables). If a significant relationship among the three variables can be developed, the trend in earnings can be predicted. The present value of firms and their human resources can be estimated by discounting the future earnings. Managerial leadership determines organizational climate which in turn influences the subordinate's satisfaction and subsequently the total productivity efficiency (Likert and Bowers, 1969).

The criticisms of all the earlier models led to the rise of a model which integrates the positive aspects of each model and by removing the limitations of the earlier models. This led to the rise of the contribution-based model (Singh, 2002a), which has been used in the study.

After analyzing the individual employee's contribution towards the organization based on HRIS (Singh, 2002a) model, we accepted the first alternative hypothesis that there is a statistically significant difference between the cost incurred on individual employees and employee value. The HRIS (Singh, 2002a) model considers both the monetary and the non-monetary variables like the Performance Appraisal Index, Experience Index, Potential appraisal index, Job Satisfaction Index while calculating the human resources accounting value of an organization's employee. These non-monetary variables have a causal effect on the value of employees in an organization.

The importance of this aspect was also emphasized by (of the Committee on Human Resource Accounting, 1973), which suggested that considering the non-monetary variables and monetary variables together to know the exact contribution of human resources towards an organization is important.

The problem of predicting the expected tenure or promotion chances of individual employees was the catalyst for Bikki Jaggi and Hon Shiang Lau in suggesting the valuation of human resources on a group basis. A homogeneous group of employees who may not be necessarily working in the same department may contribute more towards the organization as a group (Jaggi and Lau, 1974). The group valuation concept can be usefully employed to determine the value of the human resources of a firm. The information generated on such a basis will be more reliable and can be used for decisions relating to human resources.

Analyzing the employees' value as a group contribution towards the organization, we cannot consider the expenditure incurred by the organization on a group of employees as a sole criterion for human resource contribution as a group.

Further analyzing the group of employees' contributions towards the organization with the help of the second hypothesis of the study and found a statistically significant difference between the cost incurred on a group of employees and the employees' value as a group calculated as per Human Resource Information System (HRIS) (Singh, 2002a). These non-monetary variables create a causal effect on the value of employees.

\subsection{Conclusions}

After the emergence of the idea to identify, measure and communicate information about human resources, a lot of effort has been made by several researchers and professionals to quantify the same. The task of developing HRA valuation and practices is assigned to accountants. Initially, for the valuation of human resources as an asset, they estimated the value of human resources based on the historical cost method that is the acquisition cost considering the conventional accounting treatments of asset valuation. But this idea was criticized and other costbased valuation methods like the replacement cost method and opportunity cost method were suggested but they were also found to have limited applications. 
In response to the cost-based valuation models, counter-arguments made by the authors, researchers, and professionals that cost-based valuation cannot help in the proper valuation of human resources. They suggested valuing human resources with the use of economic value-based models. Economic valuation models were advocating the valuation of human resources based on the present value of the future expected return of an employee. Even economic value-based models were not widely accepted and faced criticism. This led to the development of the non-monetary-based valuation of human resources.

The results of this study indicate that the financial expenditure incurred by the organization on their employees is not the sole criteria for valuing the contribution of employees towards the organization. The conventional accounting method used money as its basic unit of measurement, (of the Committee on Human Resource Accounting, 1973) in a Statement of Basic Accounting Theory recently found that there is no reason to consider money as alone unit of measurement (The committee stated that "there is also no reason why the only measure applied should be 'value' in terms of dollars) and recommended that it is completely feasible that there should be other units of measurement in accounting systematically. The committee suggested that in the future, there was scope in future to include non-monetary as well as monetary measures in accounting (of the Committee on Human Resource Accounting, 1973). With monetary variables, many non-monetary variables like job satisfaction, performance appraisal, potential appraisal, organization climate (Singh, 2002a), transferability, profitability Satisfaction, Skills (Taylor and Bowers, 1972)) were found to be useful for decision-making purposes.

After understanding the results from this study, a measurement-based model can be developed which consists of monetary variables as well as non-monetary variables, which can only provide information about the actual contribution of employees towards the organization. Considering only one monetary or non-monetary variable at a time, will not provide the actual value of the contribution made by employees towards the organization. From the data analysis results, we also conclude at the individual employee level that there is a difference between the expenditure incurred by the organization on their employees individually and the Value of individual employees' contribution towards the organization, and we found that the value of an individual employee and value as a group of the employees is higher than the cost incurred by the organization on their employees. This means that the contributions made by the employees both individually as well as collectively are much more than the cost incurred on the employees by the organization.

\subsection{Implications of the study}

Corporations can calculate the actual value of employee contribution towards the organization, and they can put such information in financial reports also, as the human resource accounting information in financial reports impacts positively the investor while making investment decisions. (Singh and Gupta, 2014). The organizations should retain the employees having higher contribution towards the organization. Human resource accounting information is important for decision-making purposes related to human resources.

\subsection{Limitations and Scope for Future Research}

The study is limited to the data collected from one company; future studies can consider more companies from one or more countries. That can provide a more realistic position of the value of human resources, as there will be a comparison with other organizations. Due to changes in the decision-making based country/region of respondents, there may be a change in the value of monetary and non-monetary variables. So, a cross-culture study can be conducted with the help of a comparative study between organizations from different-different countries.

As the HRIS (Singh, 2002a) was developed based on four non-monetary variables: job satisfaction, potential appraisal, performance appraisal, organization climate; future studies may consider other non-monetary variables that may also contribute towards the valuation of human resources.

\begin{tabular}{|c|c|c|c|c|c|c|c|}
\hline \multicolumn{8}{|c|}{ Individual Employee Valuation as per Human Resources Information System (HRIS) (Singh, 2002) } \\
\hline Name of Company INFOSYS & $\begin{array}{c}\text { AVG Total Cost } \\
\text { (Avg Current Cost }+ \text { Avg Future Cost) }\end{array}$ & KPA INDEX & JS INDEX & PA INDEX & EXP INDEX & $\begin{array}{l}\text { HUMAN RESOURCES VALUE } \\
\text { (INDIVIDUAL EMPLOYEE) }\end{array}$ & $\begin{array}{l}\text { Human Resources } \\
\text { Value Ranking }\end{array}$ \\
\hline INFOSYS15 & 2099550 & 1.5217391 & 1.6 & 1.925926 & 2 & 10155241.44 & 82 \\
\hline INFOSYS22 & 2099550 & 1.3043478 & 1 & 1.203704 & 10.5 & 28683416.74 & 30 \\
\hline INFOSYS93 & 2099550 & 1.9347826 & 1.5 & 1.962963 & 6 & 36179405.91 & 15 \\
\hline
\end{tabular}

\section{References}

Abiola, J.O., Adisa, R.A., 2020. Influence of human resource accounting practices on managerial decision-making. Archives of Business Review 8(5), 8-18.

Al-Tahat, S.S., Al-Zoubi, A.M., 2020. The challenges in applying human resources accounting in auditing companies. International Journal of Business and Social Science 11(3), 170-180. 
Arkan, T., 2016. Human resources accounting: A suggested model for measurement and valuation. Finanse, Rynki Finansowe, Ubezpieczenia nr 79(13), 173-193.

Ashford, S.J., 1988. Individual strategies for coping with stress during organizational transitions. The Journal of Applied Behavioral Science 24(1), 19-36. URL: https://doi.org/10.1177/0021886388241005.

Avazzadehfath, F., Raiashekar, H., 2011. Decision-making based on human resource accounting information and its evaluation method. Asian Journal of Finance \& Accounting 3(1), 1-13. URL: https://doi:10.5296/ajfa.v3i1.883.

Baligh, H., H., .

Bechtel, R., 2007. Calculating human capital: The market based valuation of the human resource. German Journal of Research in Human Resource Management. 21(3), 206-231. URL: https://www.jstor.org/stable/23278557.

Brayfield, A.H., Rothe, H.F., 1951. An index of job satisfaction. Journal of Applied Psychology 35(5), 307-311. URL: https://doi.org/10.1037/h0055617.

Brummet, R., Flamholtz, E., Pyle, W., 1968. Human resource measurement - a challenge for accountants. The Accounting Review 43(2), 217-224. URL: https://www.jstor.org/stable/243757.

Chouhan, V., Naghshbandi, N., 2015. Measuring employees value: A critical study on human resources accounting in india. International Journal of Management, Accounting and Economics 2(4), 277-292.

Dbie-RBI, 2020. Database on indian economy. URL: https://dbie.rbi.org.in/DBIE/dbie.rbi?site=home.

Dittman, D., Juris, H., Revsine, L., 1980. Unrecorded human assets: A survey of accounting firms' training programs. The Accounting Review 55(4), 640-648. URL: https://www.jstor.org/stable/245782.

Do, D.T., Btran, I.M., Nguyen, T.N., Truong, D.D., Tran, M.D., 2019. Determinants influencing the quality of accounting human resources: The case of hanoi, vietnam. $10^{t} \mathrm{~h}$ Neu-Kku International Conference Socio-Economic and Environmental 10(1), 711-726.

Eby, L.T., Dobbins, G.H., 1997. Collectivistic orientation in teams: An individual and group-level analysis. Journal of Organizational Behavior 18(3), 275-295. URL: https://doi .org/10.1002/(SICI) 1099-1379(199705) 18:3<275: : AID-JOB796>3.0.CO;2-C.

Elias, N., 1972. The effects of human asset statements on the investment decision: An experiment. Journal of Accounting Research 10(1), 215-233. URL: https://doi.org/10.2307/2489876.

Enyi, E.P., Akindehinde, A.O., 2014. Human resource accounting and decision making in post-industrial. International Journal of Accounting and Taxation 2(1), 19-35.

Flamholtz, E., 1971. A model for human resource valuation: A stochastic process with service rewards. The Accounting Review 46(2), 253-267.

Flamholtz, E., 1972a. Assessing the validity of a theory of human resource value: A field study. Journal of Accounting Research 10(1), 241-266. URL: https://doi.org/10.2307/2489878.

Flamholtz, E., 1972b. Towards a theory of human resource value in formal organizations. The Accounting Review 47(4), 666-678. URL: https://www.jstor.org/stable/245330.

Flamholtz, E., 1973. Human resources accounting: Measuring positional replacement costs. Human Resource Management Spring, 8-16. URL: https://doi.org/10.1002/hrm. 3930120103.

Flamholtz, E.G., Bullen, M.L., Hua, W., 2002. Human resource accounting: A historical perspective and future implications. Management Decisions 40 (10), 947-954.

Flamholtz, E.G., Main, E.D., 1999. Current issues, recent advancements and future directions in human resource accounting. Journal of Human Resource Costing \& Accounting 4(1), 11-20. URL: https://Doi.0rg/10.1108/Eb029050.

Friedman, A., Lev, B., 1974. A surrogate measure for the firm's investment in human resources. Journal of Accounting Research 12(2), 235-250. URL: https://doi.org/10.2307/2490374.

Gambling, T., 1974. A system dynamics approach to human resource accounting. The Accounting Review 49(3), 538-546. URL: https://www.jstor.org/stable/244617.

Hanini, E.A., 2018. Evaluation of measurement and disclosure methods of human resources accounting in public shareholding companies in jordan. Academy of Accounting and Financial Studies Journal 22(4), 1-11.

Hendricks, J., 1976. The impact of human resource accounting information on stock investment decisions: An empirical study. The Accounting Review 51(2), 292-305. URL: https://www.jstor.org/stable/244840.

of the Committee on Human Resource Accounting, R., 1973. The Accounting Review 48(1), 169-185. URL: https: //www.jstor.org/stable/3203238.

Isaac, O.I., Mayor, B.M., James, O., 2017. Human capital accounting and market value of oil and gas companies in nigeria. International Journal of Innovative Research in Science, Engineering and Technology 6(11), $21364-21369$.

Jaggi, B., Lau, H., 1974. Toward a model for human resource valuation. The Accounting Review 49(2), 49(2). URL: https://www . jstor.org/stable/245105.

Jaggi, B., Lau, H., 1975. Toward a model for human resource valuation: A reply. The Accounting Review 50(2), 348-350. URL: https://www.jstor.org/stable/244717.

Jimmieson, N.L., Terry, D.J., Callan, V., 2004. A longitudinal study of employee adaptation to organizational change: the role of change-related information and change-related self-efficacy. Journal of Occupational Health Psychology 9(1), 11-27. URL: https://doi.org/10.1037/1076-8998.9.1.11.

Judge, T.A., Locke, E.A., Durham, C.C., Kluger, A.N., 1998. Dispositional effects on job and life satisfaction: The role of core evaluations. Journal of Applied Psychology 83(1), 17-34. URL: https://doi .org/10.1037/0021-9010.83.1.17.

K., G.R., K, S.P.C., 2016. Hrd interventions, employee competencies and organizational effectiveness: an empir- 
ical study. European Journal of Training and Development 40(5), 345-365. URL: https://dx.doi.org/10.1108/ EJTD-02-2016-0008.

Katz, D., Maccoby, N., Gurin, G., Floor, L.G., 1951. Productivity, supervision and morale among railroad workers, MI: Survey Research Center. Institute for Social Research,University of Michigan, Ann Arbor.

Likert, R., 1967. The human organizations. New York: McGraw-Hill.

Likert, R., 1973. Human resource accounting: Building and assessing productive organizations. Personnel 50(3), 8-24.

Likert, R., 1977. Human resources and human resources accounting. in b. b. wolman (ed.). International Encyclopedia of Neurology, Psychiatry, Psychoanalysis and Psychology (7).

Likert, R., 1979. From production- and employee-centeredness to systems. Journal of Management 5(2), 147-156. URL: https://doi.org/10.1177/014920637900500205.

Likert, R., Bowers, D.G., 1969. Organizational theory and human resource accounting. American Psychologist 24(6), 585-592. URL: https://doi.org/10.1037/h0028020.

Likert, R., Bowers, D.G., 1973. 'improving the accuracy of p/l reports by estimating the change in dollar value of the human organization'. Michigan Business Review 25(1), 15-24.

Likert, R., Pyle, C.W., 1971. Human resource accounting: A human organizational measurement approach. Financial Analysts Journal 27(1), 75-84. URL: https://doi.org/10.2469/faj.v27.n1.75.

Likert, R.A., 1932. Technique for the measurement of attitudes. Archives of Psychology 140(1), 1-55.

More, N., Reimer, E., 1956. The experimental change of a major organizational variable. Journal of Abnormal Social Psychology 52(1), 120-129.

Morse, N., 1953. Satisfactions in the white-collar job .

Morse, W., 1973. A note on the relationship between human assets and human capital. The Accounting Review 48(3), 589-593. URL: https://www.jstor.org/stable/245156.

Morse, W., 1975. Toward a model for human resource valuation: A comment. The Accounting Review 50(2), 345347. URL: https://www. jstor.org/stable/244716.

Pecorella, P., Bowers, D.G., Davenport, A.S., Lapointe, J.B., 1978. Forecasting Performance in Organizations: An Application of Current Value Human Resources Accounting. Institute for Social Research, University of Michigan, Ann Arbor.

Ployhart, R., Moliterno, T., 2011. Emergence of the human capital resource: A multilevel model. he Academy of Management Review 36(1), 127-150. URL: https://www.jstor.org/stable/29765018.

Ryder, P., 1975. The role of behavioral measures in accounting for human resources: A comment. The Accounting Review 50(3), 574-578. URL: https://www.jstor.org/stable/245014.

Sharma, R.B., Sharma, A., 2013. Practicing of human resources accounting in infosys limited. European Journal of Commerce and Management Research 2(3), 57-63.

Sinclair, K., 1991. Accounting for human resource expenditures and internal performance evaluation: Some evidence. Journal of Managerial Issues 3(3), 319-334. URL: https://www. jstor.org/stable/40603729.

Singh, A.K., 2002a. Accounting for Human Resource: Acquisition, Development and Retention. Society for Human Transformation and Research, Delhi.

Singh, A.K., 2002b. Human development: A holistic perspective for developing transformational leadership from within. Delhi Business Review 3(1), 29-45. URL: https://papers.ssrn.com/sol3/papers.cfm?abstract_id=2113979.

Singh, A.K., Gupta, N., 2008. Measurement of human asset: An empirical analysis. Indian Journal of Accounting 38(2), 13- 22.

Singh, A.K., Gupta, N., 2010. Contribution based measurement of human asset for strategic decision making using hcis. International Journal of Business and Management Studies 2(1), 97-105.

Singh, A.K., Gupta, N., 2014. Metrics for human assets: An empirical analysis of the current practice in service sector organizations in india. Amity Business Review 15(1), 20-30.

Singh, A.K., Jain, S., 2013. Employer branding: A tool for motivating and retaining employees. Indian Journal of Current Trends in Management Sciences 6(1), 1-14. URL: https://papers.ssrn.com/sol3/papers.cfm?abstract_id= 2290592.

Singh, A.K., Sharma, V., 2011a. Key attributes of successful knowledge management: An empirical study in telecommunication and software industries. International Journal of Business Information Systems, Inderscience Journal 7(1), 78-92. URL: https://www. inderscience.com/search/index.php?action=record\&rec_id=372982.

Singh, A.K., Sharma, V., 2011b. Knowledge management antecedents and its impact on employee satisfaction: A study on indian telecommunication industries. Learning Organization, The - TLO 18(2), 115-130. URL: https: //www. emeraldinsight.com/10.1108/09696471111103722.

Singh, A.K., Vasudeva, S., 2014. Unethical financial reporting: An empirical analysis of causes and consequences. MUDRA: Journal of Finance and Accounting 1(1), 1-30. URL: https://doi.org/10.17492/mudra.v1i1.2454.

Sinha, S., Singh, A.K., Gupta, N., 2010. Impact of work culture on motivation level of employees in selected public sector companies in india. Delhi Business Review 11(1), 43-54. URL: https://www.delhibusinessreview.org/v11n1/ v11n1d.pdf.

Suarez, E.P., Muniz, J., Alvarez, A.C., F., P.E., G, C.E., 2013. Assessing organizational climate: psychometric properties of the clior scale. Psicothema 25(1), 137-144. URL: https://doi.org/10.7334/psicothema2012.260. 
Tafarodi, R.W., Swann, W. B., J., 1995. Self-liking and self-competence as dimensions of global self-esteem: Initial validation of a measure. Journal of Personality Assessment 65(2), 322-342. URL: https://doi.org/10. 1207/s15327752jpa6502_8.

Taylor, J., Bowers, D.G., 1972. Survey of organizations: Toward a machine-scored, standardized questionnaire instrument .

Wiemann, J.M., 1977. Explication and test of a model of communicative competence. Human Communication Research 3(3), 195-213. URL: https://doi.org/10.1111/j.1468-2958.1977.tb00518.x. 